\title{
Post Danmark II, Now Concluded by the ECJ Clarification of the Rebate Abuse, But How do We Marry Post Danmark I with Post Danmark II?
}

\author{
Lundqvist, Björn
}

Document Version

Accepted author manuscript

Published in:

European Competition Journal

DOI:

$10.1080 / 17441056.2016 .1152846$

Publication date:

2016

License

Unspecified

Citation for published version (APA):

Lundqvist, B. (2016). Post Danmark II, Now Concluded by the ECJ: Clarification of the Rebate Abuse, But How do We Marry Post Danmark I with Post Danmark II? European Competition Journal, 11(2-3), 557-573.

https://doi.org/10.1080/17441056.2016.1152846

Link to publication in CBS Research Portal

\section{General rights}

Copyright and moral rights for the publications made accessible in the public portal are retained by the authors and/or other copyright owners and it is a condition of accessing publications that users recognise and abide by the legal requirements associated with these rights.

\section{Take down policy}

If you believe that this document breaches copyright please contact us (research.lib@cbs.dk) providing details, and we will remove access to the work immediately and investigate your claim. 


\section{Post Danmark II, Now Concluded by the ECJ: Clarification of the Rebate Abuse, But How do We Marry Post Danmark I with Post Danmark II?}

\section{Björn Lundquist}

Journal article (Post print version)

Cite: Post Danmark II, Now Concluded by the ECJ: Clarification of the Rebate Abuse, But How do We Marry Post Danmark I with Post Danmark II? / Lundqvist, Björn. In: European Competition Journa/, Vol. 11, No. 2-3, २०16, p. 557-573.

This is an Accepted Manuscript of an article published by Taylor \& Francis in European Competition Journa/on 29 March 2016, available online: http://dx.doi.org/10.1080/17441056.2016.1152846

Uploaded to Research@CBS: April २०17 


\title{
Post Danmark II, now Concluded by the ECJ: \\ Clarification of the Rebate Abuse, but how do we marry Post Danmark I with \\ Post Danmark II?
}

\author{
Björn Lundqvist* \\ Copenhagen Business School, Copenhagen, Denmark; Stockholm University, Stockholm, \\ Sweden
}

\begin{abstract}
- In this article, the Post Danmark II judgement is discussed and analysed in the light of recent rulings by the Court of Justice (ECJ) and the General Court (together CJEU).

- The article quickly resolves that it is clear that the ECJ with Post Danmark II has, generally and rather stubbornly, kept the competition law doctrine for rebates unchanged and, more specifically, made it obvious that the ECJ does not support a general as-efficient-competitor test in the rebate abuse arena.

- However, the article continues and concludes that by clinging on to the competition law doctrine regarding rebate schemes, while making changes to the price discrimination test in Post Danmark I, the ECJ creates unease in the interface between pricing abuses, rebate abuses and discrimination according to Article 102 (c) TFEU.

- The legal technical unease can only be resolved by acknowledging that selective low pricing, selective targeted rebates as exclusionary abuses, and price discrimination under Article 102(c) TFEU should, according to ECJ, be treated rather differently, making it difficult for a dominant firm to respond to new entrants in a way that actually mirrors 'competition on the merits'.
\end{abstract}

\section{Introduction}

On 6 October 2015, the ECJ handed down its ruling in Post Danmark $I^{l}$ (occasionally hereinafter referred to as PD II), and with that provided guidance on how to assess the legality

\footnotetext{
* *LL.D (EUI), LL.M (Michigan), Associate Professor of EU Competition Law, Copenhagen Business School, Senior lecturer, Juridicum, Stockholm University. Email: bjorn.lundqvist@juridicum.su.se ${ }^{1}$ C-23/14 Post Danmark A/S v. Konkurrencerådet, EU:C:2015:651.
} 
of rebate schemes under EU competition law. The questions sent by the Danish court to the ECJ were aiming at the core of the EU Competition Law rebate abuse doctrine. ECJ was asked to clarify, in light of the old rebate case doctrine, the Commission Guidance Paper ${ }^{2}$ from 2009 regarding the application of Art. 102 TFEU, so to enable the Danish court to pin down when to use the so-called as-efficient-competitor test. In general, the Danish court asked how the rebates under Article 102 TFEU should be judged under a more 'economic approach'. More specifically, the Danish Court, inter alia asked: (i) the criteria to be applied in determining whether a rebate scheme is abusive; (ii) the relevance of the as-efficientcompetitor test in determining whether a rebate scheme is abusive; and, (iii) which level of proof is needed to establish an anticompetitive effect. Indeed these are basic questions that should have been answered long ago, given that rebates have been judged under EU Competition Law since Hofmann-La Roche $e^{3}$ in 1979.

The ECJ in PD II answered: (i) When the rebate scheme can neither be regarded as a loyalty inducing scheme, nor as a pure quantitative discount, it is necessary to examine all the circumstances of the case, including the criteria and rules governing the grant of the rebates, the extent of the dominant position of the undertaking concerned, and the particular conditions of competition prevailing on the relevant market. The application of the 'asefficient-competitor' test (ii) does not constitute a necessary condition for a finding to the effect that a rebate scheme is abusive under Article 102 TFEU. Indeed, in the case at hand (Post Danmark II), applying the as-efficient-competitor test is of no relevance according to the ECJ. To establish an abuse (iii), the anti-competitive effect of a rebate scheme operated by a dominant undertaking must be probable, however, there is no need to show that the effect is of a serious or appreciable nature.

The former incumbent state-owned post monopolist Post Danmark has provided us with great opportunity to revisit the old case law regarding rebates and selective low pricing, and to see whether these cases have withstood the onslaught of time and the implementation of a more 'economic approach'. In 2012, the ECJ handed down its Post Danmark I (sometimes hereinafter referred to as PD I) judgement regarding selective low pricing, and even though that the low prices discussed were provided through rebates, PD I and PD II have clearly been

\footnotetext{
${ }^{2}$ Communication from the Commission: Guidance on its enforcement priorities in applying Article 82 of the EC Treaty to abusive exclusionary conduct by dominant undertakings, OJ C 45, 24.2.2009, p. 7-20

${ }^{3}$ Case 85/76 Hofmann-La Roche v. Commission EU:C:1979:36.
} 
viewed and judged differently by the ECJ. In this article, PD II is discussed and analysed in light of PD I, as well as other recent cases provided to us by the CJEU. The author concludes that in reference to a conduct that could be described as price discrimination, so-called primary line discrimination and secondary line discrimination, will in light of PD I and PD II be judged differently, one according to the as-efficient-competitor test, while the other will presumably be triggered more easily under case law of older origin.

\section{Background}

As all major cases in the EU, Post Danmark I and II have a long pre-history. The business conduct by Post Danmark, in reference to both the addressed and the un-addressed mail distribution service, has been tried by several judicial bodies, and the legal issues in each case were not as clear cut as one might have thought after reading the ECJ's preliminary rulings.

Post Danmark $I^{4}$ concerned selective low pricing based on the pricing strategy of Post Danmark given to three specific customers, the supermarkets Coop, SuperBest, and Spar in relation to their unaddressed mail marketing needs in Denmark. These three customers had

\footnotetext{
${ }^{4}$ The Post Danmark I case started in September 2004, where Konkurrencerådet (the Danish National Competition Authority, hereinafter the NCA) decided that, ultimo 2003, Post Danmark had committed in essence two kinds of pricing abuses to win the three largest customers of the only competitor on the market for distribution of unaddressed mail, Forbruger-Kontakt. Konkurrencerådets møde 29 September 2004 in case Forbruger-Kontakts klage over Post Danmarks misbrug af dominerende stilling (available at: www.kfst.dk, accessed February 2013). Forbruger-Kontakt's complaint led to several parallel cases pursued by the NCA against Post Danmark in the market for distribution of magazines and the market for direct mail. Post Danmark was allegedly in breach of Article 102(c) TFEU by, firstly, conducting selective low pricing through a rebate scheme and by offering loyalty creating target rebates to certain customers; and, secondly, by engaging in a general price discrimination strategy when, by offering different prices, not putting its customers on an equal footing in terms of rates and rebates. In a subsequent decision from November 2004, the NCA found that Post Danmark had not practiced predatory pricing, while committed other forms of abuses. Only the part of the decision on selective low pricing was appealed from the Danish Competition Complaints Board to the Danish High Court, and later to the Danish Supreme Court; and the questions sent by the Danish Supreme Court to the CJEU, concerned selective low pricing based on the pricing strategy of Post Danmark in relation to three specific customers, the supermarkets Coop, SuperBest, and Spar in Denmark. This implies, that the Competition Complaint Board's finding of a general abuse in the form of price discrimination concerning secondary line price discrimination became final, and so did the decision that Post Danmark had not engaged in predatory pricing. Konkurrencerådets møde 24 November 2004 in case Forbruger-Kontakts klage over Post Danmarks misbrug af dominerende stilling (predatory pricing). Konkurrencerådets møde 24 November 2004 in case ForbrugerKontakts klage over Post Danmarks misbrug af dominerende stilling (predatory pricing) at [129]-[139].This decision was upheld by the Competition Complaints Board in a verdict of 1 July 2005. Both are available at: www.kfst.dk, accessed July 2012. The case is discussed in Björn Lundqvist; Grith Skovgaard Ølykke 'Post Danmark, Now Concluded by the Danish Supreme Court : Clarification of the Selective Low Pricing Abuse and Perhaps the Embryo of a New Test under Article 102 TFEU?' (2013) 34 E C L R: European Competition Law Review, 9, s. 485-490
} 
been won over by a competitor of Post Danmark, and Post Danmark retaliated by giving these three customers a specific rebate system. Post Danmark $I$ was delivered by the Grand Chamber, implying that the ECJ was aware of the importance of its judgment. Indeed, it seems clear that the ECJ in Post Danmark I reshaped the selective low pricing doctrine, i.e. limited the doctrine to some effect, or rather "recalibrated" the requirements. The ECJ started by stating "...not every exclusionary effect is necessarily detrimental to competition $[\ldots]$. Competition on the merits may, by definition, lead to the departure from the market or the marginalisation of competitors that are less efficient and so less attractive to consumers from the point of view of, among other things, price, choice, quality or innovation." That is quite an opening by the Court, and it continued. Firstly, the ECJ categorically stated that stipulating different prices to different customers, i.e. price discrimination, cannot in itself be an exclusionary abuse. ${ }^{6}$ Secondly, ECJ firmly stated that selective pricing above ATC cannot have anti-competitive effects, hence, Post Danmark's prices vis-à-vis SuperBest and Spar could not be considered a form of abuse. ${ }^{7}$ Thirdly, the ECJ addressed the crucial question referred, i.e. whether, and under which circumstances, selective low pricing below ATC, but above AIC and without any intent to eliminate on the behalf of the dominant firm, can be considered an abuse. The answer given by the ECJ implies that an abuse in these circumstances can still be identified by the "efficient competitor test"; which tests whether the pricing strategy would cause anti-competitive effects. ${ }^{8}$ Indeed, the ECJ not only found a new test for identifying abuse when the dominant firm price in-between AIC and ATC, it also limited (primary line) price discrimination under Article 102 TFEU to only exist when the dominant firm set prices in order to exclude an as-efficient-competitor under the various price tests.

In reference to PD II, the case began with a complaint lodged by Post Norway's subsidiary Bring Citymail. Bring Citymail tried in the end of the first decade of 2000 to enter the Danish market for addressed mail, but exited the market soon thereafter due to heavy losses. It blamed the business conduct of Post Danmark for its failure on the Danish market. The Danish Competition Authority found, in June 2009, that Post Danmark had abused a dominant position on the market for the distribution of addressed bulk mail by applying rebates in respect of direct advertising mail, which resulted in tying customers and

\footnotetext{
${ }^{5}$ C-209/10 Post Danmark A/S v Konkurrencerådet EU:C:2012:172, para.22.

${ }^{6}$ C-209/10 Post Danmark A/S v Konkurrencerådet EU:C:2012:172, para. 30.

${ }^{7}$ C-209/10 Post Danmark A/S v Konkurrencerådet EU:C:2012:172, para. 36.

${ }^{8}$ C-209/10 Post Danmark A/S v Konkurrencerådet EU:C:2012:172, paras. 38-40.
} 
'foreclosing' the market, without being able to substantiate the efficiency gains that might have benefited consumers and neutralised those rebates' restrictive effects on competition. ${ }^{9}$

The DCA found, inter alia, that Post Danmark was an unavoidable trading partner on the bulk mail market because of its unique national distribution system. Due to the statutory monopoly, Post Danmark enjoyed significant structural advantages. During the relevant period, over $70 \%$ of all bulk mail in Denmark was covered by the monopoly, which moreover ensured a unique geographical coverage encompassing all of Denmark. ${ }^{10}$

According to the DCA, those factors obliged customers to turn to Post Danmark for the mail that was to be distributed beyond Bring Citymail's geographical coverage, which was mainly Copenhagen. $^{11}$

According to the DCA, the standardised rebate scheme that was publically available to any customer, stipulating a rebate of between 6 to $16 \%$ for letters weighing up to 100 grams and being based on the size of the aggregated purchase, was abusive in particular because it was retroactive. ${ }^{12}$ The rebate was calculated on a one-year period for the acquisition of rights and the amplitude of the rebate rates applied. Thus, at the beginning of each reference year the price payable by each customer was provisionally determined by reference to the volume that that customer was expected to post during that year. At the end of the reference year, all prices were retroactively adjusted, according to the volume of mail actually sent by that customer during the year. Any customer could obtain a higher level of rebate by posting higher volumes, but there was no requirement that it should use Post Danmark for a given proportion of its mailings in order to qualify for a rebate. ${ }^{13}$

Based on the levels and the structure of the rebate system, approximately two-thirds of direct advertising mail not covered by the monopoly could not be transferred from Post Danmark to Bring Citymail without an adverse impact on the scale of the rebates, according to the findings of the DCA. In other words, it seems that the DCA found that Post Danmark, by utilizing the fact that it held a monopoly on $70 \%$ of the market, could use the rebate system to

\footnotetext{
${ }^{9}$ C-23/14 Post Danmark A/S v. Konkurrencerådet, EU:C:2015:651, paras. 13 et seq.

${ }^{10}$ Ibid.

${ }^{11} \mathrm{Ibid}$

${ }^{12}$ Ibid.

${ }^{13}$ Ibid.
} 
leverage also the business in Copenhagen (the contestable share of the market, i.e. 30\%), while Bring Citymail had to price below (or even far below) the price with the rebate given by Post Danmark to be able to compete for the business on the contestable share of the market, at least for $2 / 3$ of the contestable market. It inferred that the scheme resulted in an anticompetitive exclusionary effect on the market. ${ }^{14}$

The DCA therefore stated, contrary to what was submitted by Post Danmark, that it was not appropriate to base the assessment of the anti-competitive exclusionary effect on the market caused by the rebate scheme on the 'as-efficient-competitor' test, but that rather a 'full legal and economic' analysis should be conducted. Moreover, according to the DCA, in the light of the particular characteristics of the relevant market, it could not be required, for the purposes of that comparison, that a new entrant should be as efficient in the short term as Post Danmark. $^{15}$

In May 2010, the Konkurrenceankenævnet (the Competition Appeals Tribunal) decided to uphold the DCA's decision. Post Danmark brought the case before the Maritime and Commercial Court (the Appeal Court), which took the view that given the inconsistency between the old case law regarding rebates and the Commission's Guidance paper regarding the enforcement of Art. 102 TFEU, certain basic questions had to be sent to the ECJ, inter alia:

- The criteria to be applied in determining whether a rebate scheme is abusive, including the relevance of the fact that the rebate scheme applies to the majority of customers on the market.

- The relevance of the as-efficient-competitor test in determining whether a rebate scheme is abusive.

- Whether a finding of abuse requires the anti-competitive effect to be probable and serious or appreciable.

\section{The ECJ judgement in Post Danmark II}

\footnotetext{
${ }^{14}$ Ibid.

${ }^{15}$ Ibid.
} 
The ECJ started by stating that it is settled case-law that quantity discount linked solely to the volume of purchases from the manufacturer concerned is not, in principle, an abuse. A loyalty rebate on the other hand, which by offering customers financial advantages tends to prevent them from obtaining most or even some of the requirements from competing manufacturers, amounts to an abuse within the meaning of that provision. ${ }^{16}$

However, according to the ECJ, the rebate system in force by Post Danmark, was neither a quantitative rebate system, nor a clear cut loyalty inducing rebate system. It was not a quantitative system since it was not linked solely to the volume of purchase because the rebates at issue were not granted in respect of each individual order and with that it was not corresponding to the cost savings made by the supplier, but instead based on the basis of the aggregate orders placed over a one year period. ${ }^{17}$

Moreover, the ECJ states that in light of the standardisation of the rebate scale, whereby all customers were entitled to receive the same rebate on the basis of the aggregated purchases over the reference period, the rebate system implemented by Post Danmark did, in principle, not result in the application of dissimilar conditions to equivalent transactions within the meaning of Article [102] c TFEU. Thus, the scheme was not discriminatory according to the Court. ${ }^{18}$ This implies that had Post Danmark provided the rebate scheme to only one class of customers, discrimination within the meaning of Article 102 (c) TFEU could have been triggered.

As will be discussed below, this statement seem to be somewhat contradictory to the statement made in PD I, where the ECJ in para 30 states that: "...the fact that the practice of a dominant undertaking may, like the pricing policy in issue in the main proceedings, be described as 'price discrimination', that is to say, charging different customers or different classes of customers different prices for goods or services whose costs are the same or, conversely, charging a single price to customers for whom supply costs differ, cannot of itself suggest that there exists an exclusionary abuse." 19

Indeed, at first glance, it seems that in PD I the ECJ required more for price discrimination to be triggered than in PD II. While the difference can be squared by acknowledging that PD I deals with primary line discrimination, i.e. that a dominant firm employ a low price so to exclude a competitor, the statement in PD II deals with

\footnotetext{
${ }^{16}$ See judgments in 322/81 Nederlandsche Banden-Industrie-Michelin v Commission, EU:C:1983:313, para 71, and C-549/10 P Tomra Systems and Others v Commission, EU:C:2012:221, para 70.

${ }^{17}$ C-23/14 Post Danmark A/S v. Konkurrencerådet, EU:C:2015:651, para. 28.

${ }^{18}$ Ibid. paras. 37 and 38.

${ }^{19}$ C-209/10 Post Danmark A/S v Konkurrencerådet EU:C:2012:172.
} 
secondary line discrimination according to Article 102 (c) TFEU, i.e. when a dominant firm give different prices downstream to two competitors, without being present downstream,. ${ }^{20}$

Since the rebate system did not fall into either category, the ECJ continues in PD II: "(...) it is necessary to consider all the circumstances, particularly the criteria and rules governing the grant of the rebate, and to investigate whether, in providing an advantage not based on any economic service justifying it, the rebate tends to remove or restrict the buyer's freedom to choose his sources of supply, to bar competitors from access to the market, to apply dissimilar conditions to equivalent transactions with other trading parties or to strengthen the dominant position by distorting competition." 21

The Court continues and gives the Danish Court some indication on what to look for when considering all circumstances.

In its fuller analysis, the ECJ notes that Post Danmark's rebates were 'retroactive', in the sense that, if the threshold initially set at the beginning of the year in respect of the quantities of mail was exceeded, the rebate rate applied at the end of the year applied to all mailings presented over the reference period, and not only to mailings exceeding the threshold initially estimated. According to the Court that creates a 'suction effect'. That 'suction effect' is further enhanced by the fact that the rebates applied without distinction both to the contestable part of demand and to the non-contestable part of demand. ${ }^{22}$

\footnotetext{
${ }^{20}$ The concept of discrimination contains an overlap, as explained by the Commission in BdKEP/Deutsche Post AG188 from 2004, when noting:

"The wording [of Article 102] covers three types of discrimination, the first two of them exclusionary and the last one exploitative: (i) the customer of the dominant firm is placed at a competitive disadvantage vis-à-vis the dominant firm itself; (ii) in relation to other customers of the dominant firm; or (iii) the customer suffers commercially in such a way that its ability to compete in whatever market is impaired. It is obvious that type (i) and (iii) do not require a competitive relationship between the two comparator groups." According to Bergqvist: "[w] hen dealing with discrimination, it is therefore relevant to differentiate b-tween: Exclusionary discrimination, sometimes referred to as primary-line-discrimination, initiated for the purpose of foreclosing competitors by targeting actual or potential customers with selective price reductions or different forms of single branding agreements and Exploitative discrimination, sometimes referred to as secondary-line-discrimination, initiated for the purpose of twisting competition in another market e.g. for the benefit of a subsidiary." Cf. Bergqvist, 'Christian, Where Do We Stand on Discounts? - A Danish Perspective' (November 11, 2015). Available at SSRN: http://ssrn.com/abstract=2642157 or http://dx.doi.org/10.2139/ssrn.2642157

${ }^{21}$ C-23/14 Post Danmark A/S v. Konkurrencerådet, EU:C:2015:651., para. 33 referring to C-95/04 P British Airways v Commission, EU:C:2007:166, para 67, and C-549/10 P Tomra Systems and Others v Commission, EU:C:2012:221, para 71.

${ }^{22}$ Ibid., para. 35. The Court continues. "that is to say, in the latter case, to addressed advertising mail weighing less than 50 grams covered by Post Danmark’s statutory monopoly."
} 
In addition, the ECJ was not pleased by the length of the reference period, stating it was "relatively long" and making reference to the judgment in Michelin. ${ }^{23}$ The Court stated that any system under which discounts are granted according to the quantities sold during a relatively long reference period has the inherent effect that at the end of that period it increases the pressure on the buyer to reach the purchase figure needed to obtain the discount or to avoid suffering the expected loss for the entire period.

The ECJ continued discussing the criteria for being considered an unavoidable trading partner, and rather transparently (implicitly) found that Post Danmark must be considered an unavoidable trading partner at the time. In those circumstances, it is particularly difficult, according to the Court, for competitors of that undertaking to outbid it in the face of discounts based on overall sales volume. ECJ finished by stating that in those circumstances, it must be held that a rebate scheme operated by an undertaking, such as the scheme at issue in the main proceedings, which, without tying customers to that undertaking by a formal obligation, nevertheless tends to make it more difficult for those customers to obtain supplies from competing undertakings, produces an anti-competitive exclusionary effect. ${ }^{24}$ In the end, the ECJ took the time to careful indicate, that a dominant undertaking may always provide justification for otherwise proven abusive behaviour. ${ }^{25}$

Thereafter, the ECJ turned to the as-efficient-competitor test and, to put it mildly, indicated that it is not the only test to be used for establishing whether a rebate scheme is abusive, but that it is one out of several tools that may be used to assess whether there is an abuse. The Court even admitted that, according to the prevailing EU doctrine, also a not as efficient competitor might contribute to intensifying the competitive pressure on that market, and may still exert constraint on the conduct of the dominant firm. ${ }^{26}$

Lastly, the Court concluded by stating that the anticompetitive effects of a rebate scheme implemented by a dominant firm must be probable, not purely hypothetical, and that there is no need to show that the rebate scheme is of serious or appreciable nature. Moreover, due the

\footnotetext{
${ }^{23} 322 / 81$, Nederlandsche Banden-Industrie-Michelin v Commission, EU:C:1983:313, para 81

${ }^{24}$ See, to that effect, judgment in C-549/10 P Tomra Systems and Others v Commission, , EU:C:2012:221, para 72 .

${ }^{25}$ C-23/14 Post Danmark A/S v. Konkurrencerådet, EU:C:2015:651, paras. 40 et seq.

${ }^{26}$ Ibid, paras. 61 and 62.
} 
fact that dominant firm has special responsibilities, the ECJ see no room for a de minimisthreshold in reference to anti-competition effects. ${ }^{27}$

\section{Analysis}

Post Danmark II is the third key ruling on rebates by the CJEU that has taken place within a couple of years, and the second key ruling within the space of 15 months. In March 2012, Post Danmark I was decided, and in June 2014, the General Court issued its judgment in Intel's appeal against the EU Commission decision imposing a $€ 1.06$ billion fine for having operated an anti-competitive rebate scheme (now on appeal to the ECJ). ${ }^{28}$ All these cases deal with rebates and all seem to deal with so-called unavoidable trading partners.

In Intel, the General Court, making reference to the old case law, drew a distinction between:

(i) Quantity rebates, which are linked solely to the volume of purchases and reflect the lower costs of supply as a result of efficiencies and economies of scale. Such pure quantity rebates are generally not considered to have foreclosure effects; ${ }^{29}$

(ii) Exclusivity rebates, which are by their very nature capable of restricting competition (under the famous passage in Hoffman-La Roche ${ }^{30}$, if the rebate scheme has the same effect as loyalty rebate or an exclusive purchasing agreement, implying that the customer obtains most of its requirements from the undertaking in a dominant position, it is per se abusive; and

(iii) Other rebates, which have a fidelity-inducing effect, which need to be examined on a case-by-case basis, taking into account all the circumstances of the individual case.

Most probably, the ECJ would have placed the rebate scheme analysed in Post Danmark II in group three; other rebates. It was fidelity-inducing due to its 'suction effect' and its long reference period of one year. From previous case law we know that three months reference period is still, as a rule of thumb, the outer limit. ${ }^{31} \mathrm{~A}$ rebates scheme being even quantitative

\footnotetext{
${ }^{27}$ Ibid, para. 63 et seq.

${ }^{28}$ T-286/09 Intel v Commission, EU:T:2014:547, appealed C-413/14 P - Intel Corporation.

${ }^{29} \mathrm{~T}-286 / 09$ Intel $v$ Commission, EU:T:2014:547, para. 75.

${ }^{30}$ Case 85/76 Hofmann-La Roche v. Commission EU:C:1979:36, paras 89-90.

${ }^{31}$ The Court has refused to give a clear reference period. See case T-203/01, Michelin II EU:T:2003:250, para. 85. See also case 322/81, Michelin I, EU:C:1983:313, para 85 et seq.
} 
should have a shorter reference period. ${ }^{32}$ The General Court in Intel also concluded that in assessing the third category of "other rebates", it is not essential to carry out an as-efficientcompetitor analysis. ${ }^{33}$ Post Danmark II does not rule out this type of effects based analysis in respect of this type of rebate. However, the ECJ in PD II also states that it is not the exclusive test for this group. Indeed, when the evidence suggests that the rebate system has a fidelityinducing effect, e.g. suction effect, the plaintiff has established a primia facia case. There is no need to establish whether a hypothetical competitor, as efficient as the dominant firm, would not be able to conduct its business due to the dominant firm's price level being below its costs. Indeed, only the fidelity (antitrust harm) and its logical effects needs to be proven.

The ECJ in PD II stated that the as-efficient-competitor test could be used, but not exclusively, for group (iii) rebates. However, also for the first group, in the list above, the asefficient-competitor test must have an application. According to the Court, quantitative rebates are in principle excluded from the liability under Article 102 TFEU if they reflect the lower costs of supply as a result of efficiencies and economies of scale. Indeed, there is a cost based test under group (i). However, in order to give room for competition, i.e. that the dominant firm must be allowed to slash it's profit margins in the face of competition by lowering prices through rebates, the dominant firm still needs to take into consideration that the test for pricing abuses may be triggered, cf. the Post Danmark I case doctrine. In other words, there must be a flexible test for a situation in which a dominant firm, through a rebate scheme, lower its prices without a connection to cost savings but without pricing below its costs. A dominant firm must be able to decide to lower its profit margins while not pricing under its costs without running the risk of abusing its dominant position. The obvious situation being that it faces competition in a certain segment and decrease prices by expanding or implementing a rebate scheme for this segment.

Moreover, according to the General Court, we seem to also have objective (per se) violations of Art. 102 TFEU, which is conduct that is not 'competition on the merits'. In Intel, the General Court states: ${ }^{34}$

Next, it should be pointed out that, for the purposes of applying Article [102 TFEU], showing an anti-competitive object and an anti-competitive effect may, in some cases,

\footnotetext{
${ }^{32}$ Ibid.

${ }^{33}$ T-286/09 Intel v Commission, EU:T:2014:547.

${ }^{34}$ T-286/09 - Intel v Commission, EU:T:2014:547, paras 204 and 205.
} 
be one and the same thing. If it is shown that the object pursued by the conduct of an undertaking in a dominant position is to restrict competition, that conduct will also be liable to have such an effect [...]. Lastly, it must be stated that an undertaking in a dominant position has a special responsibility not to impair, by conduct falling outside the scope of competition on the merits, genuine undistorted competition in the common market [...]. The grant of payments to customers in consideration of restrictions on the marketing of products equipped with a product of a specific competitor clearly falls outside the scope of competition on the merits.

In summary, Intel and PD II tells us that there is a clear difference between pricing abuses, such as the one in Post Danmark I, and rebates, as in Tomra and Post Danmark II. In fact, when taking the recent cases, Intel, Post Danmark II and Tomra, into consideration, the ECJ seems to be slowly but steadily reestablishing the old line of case law and mapping out an abuse doctrine in three to five limbs:

(i) the first limb, as explained in Intel, tells us that there are naked restraints conduct that is plainly not 'competition on the merits' and which a dominant firm may not pursue (per se anticompetitive because anticompetitive effects are obvious).

(ii) the second limb is whether the dominant firm is implementing a loyalty rebate scheme that we from previous cases know as an 'exclusive scheme'. To establish whether there is an exclusive scheme, the Court is required to have a quick look at the circumstances of the case, foremost the terms and conditions for the rebate scheme;

(iii) the third or (third A) limb, is whether the dominant firm is employing a scheme that merits a full analysis, taking into consideration all circumstances of the case if it potentially risks to cause loyalty, i.e. it has a fidelity-inducing effect $(P D$ II, Intel, Tomra, and Hoffman La-Roche). In this group, the dominant firm often has to be an unavoidable trading partner and employ fidelity-inducing rebate scheme, e.g. retroactive rebates with suction effects that has at least 'probable' exclusionary effects. The exclusionary effects may be derived from the fact that the rebate scheme is based on the whole market, i.e. also non-contestable shares of the market;

(iv) the third B (or fourth) limb, which is only relevant if the rebate scheme is not exclusive or has a fidelity-inducing effect, but it is unclear if the quantitative or selective rebate scheme still may cause prices that exclude an "as efficient" competitor (i.e. to exclude/foreclose competition on an economic basis) (see Post 
Danmark $I$ for price discrimination and the general reference to that the asefficient competitor test may, as one tool of may, be used in these situations in Post Danmark II), and

(v) there is also a fourth or fifth limb, the per se legal rebates. These are quantitative rebates where the rebates that are linked solely to the volume of purchases and reflect the lower costs of supply as a result of efficiencies and economies of scale. Such pure quantity rebates falls, in principle, outside Article 102 TFEU. Moreover, when customers are entitled to receive the same rebate on the basis of the aggregated purchases over the reference period, the rebate system does not, in principle, result in the application of dissimilar conditions to equivalent transactions within the meaning of Article [102] c TFEU.

The Third B, or forth limb, is important. If Post Denmark I should not be considered at least partially overruled, a dominant firm must be able to employ not only a selective low price scheme, but also a selective rebate scheme, which means it would give rebates to a selected few firms so to fend off a competitor under the as-efficient-competitor test, irrespectively of whether the rebate scheme would be applied different vis-à-vis different customers. Indeed, one of the innovative steps taken by the ECJ in Post Danmark I was stipulating that different prices to different customers, i.e. price discrimination, cannot in itself be an exclusionary abuse. Secondly, the ECJ firmly stated that selective pricing above Average Total Cost (ATC) cannot have anti-competitive effects. This would imply that also dominant firms can compete by lowering prices so to beat competition where competition happen, as long as the asefficient-competitor test is not violated.

In light of Post Danmark I, if Post Danmark in PD II only had employed a short period based rebate scheme for the contested market, would such a rebate have been judged under the asefficient-competitor test, i.e. under the Third B or the fourth limb? This is a quite important question since firms (also dominant firms) compete by responding to competitive pressure. Also dominant firms should be allowed to decrease prices through rebates in the segments where they face competition, while keeping the price levels intact in other segments. If the dominant firm chooses to do so through a rebate scheme or through a selective pricing scheme, should make no difference. The scheme should not be regarded as fidelity-inducing, nor as price discrimination. 
However, the ECJ stated in Post Danmark II that the standardised open rebate system employed implied that aggregated purchases over the reference period triggered the rebate, and this supports the conclusion that in principle the rebate system implemented by Post Danmark did not result in the application of dissimilar conditions to equivalent transactions within the meaning of Article [102] c TFEU. The ECJ seems to imply, e'contrario, that should Post Danmark have applied dissimilar rebates to equivalent transactions, Article 102 [c] TFEU would (in principle) have been breached. Given the ECJ's finding in Post Danmark $I$, that different prices does not automatically call for discrimination, the statement in Post Danmark II needs some more clarification. Could Post Danmark have employed a rebate scheme only for Copenhagen (where it faced competition), or would that have meant that Article 102 (c) TFEU would have been breached?

It is certainly clear that previous case law indicates that rebates can easily violate Article 102 (c) TFEU. In the Soda Ash case ${ }^{35}$, the Commission (and indirectly the court) condemned a pricing structure based on top slice rebates whereby customers got the basic demand, which they would have purchased from the dominant firm at a normal price, but where offered substantial discounts on the extra amounts of which they had a choice of suppliers. The rebate system was held to be a loyalty-inducing rebate system but also in violation of Article 102 [c] TFEU since it was discriminatory, while giving customers different prices. ${ }^{36}$

However, it is in the Irish Sugar case that the Court found that Article 102 (c) TFEU to be easily triggered when a dominant firm has employed a selective low rebate system.

In Irish Sugar ${ }^{37}$, the Commission (and the CJEU agreed) found that Irish Sugar [together with SDL] took measures to restrict imports from Northern Ireland, particularly in the period 1985 to 1988 , by pursuing a policy of selective or discriminatory pricing on the Irish sugar market. This policy included the grant of special allowances to selected customers. In particular, a special rebate was granted to certain customers established in the border area to Northern Ireland (the border rebate). The border rebate was unrelated to objective economic factors like the sales volume of the customers. It was used and modulated whenever it was considered that

\footnotetext{
${ }^{35}$ T-57/01, Soda-Solvay, EU:T:2009:519, paras. 28, 189, 203, 214, and 316.

${ }^{36}$ Ibid.

${ }^{37}$ T-228/97, Irish Sugar, EU:T:1999:246, paras. 173 et seq.
} 
the price difference between Northern Ireland and Ireland might have induced competition from the other side of the border.

The Commission concluded: 'the application of the border rebate is an abuse of Irish Sugar's and SDL's joint dominant position within the meaning of Article [102 TFEU]. In fact, it means that Irish Sugar/SDL have been applying dissimilar conditions to equivalent transactions with other trading parties, thereby placing those who did not qualify for the rebate at a competitive disadvantage. Moreover, this rebate was intended to, and did, deter imports of sugar from Northern Ireland, whether imports of sugar from Irish Sugar's competitors or reimports of its own sugar, thus limiting markets to the prejudice of customers. Irish Sugar did not deny that it granted a special rebate based on geographic location to certain retailers established along the border with Northern Ireland to compete with cheap imports of sugar from Northern Ireland intended for retail sale. Irish Sugar tried to defend its border rebate by stating that by being threatened with the loss of part of its customer base and its turnover it decided to face the competition where it manifested itself, using the limited means that its financial difficulties left it with at the time. It thus claimed that it was financially unable to cut prices on a national scale, while it lowered prices in the geographic segment faced competition. Irish Sugar further argued that it was contradictory to claim on the one hand that an undertaking in a dominant position undoubtedly has the right to defend its position by competing with other undertakings on its market, and at the same time to regard it as an abuse for an undertaking in a dominant position to defend that position successfully. CJEU did not agree with Irish Sugar and found that the Commission was right in finding an abuse. $^{38}$

Irish Sugar has been heavily criticised over the years by several commentators. ${ }^{39}$ I have been arguing elsewhere that the ECJ's statements in $P D I$ clarified that when a dominant firm gives selective low prices, which still creates final prices that are above the dominant firms costs and by such action fends off a competitor, that action should be judged under the as-efficientcompetitor test. PD I should be seen as a limitation of the peculiar line of case law, notably in

\footnotetext{
${ }^{38}$ Ibid., para. 173.

${ }^{39}$ For example, Rousseva and Marquis, 'Hell Freezes Over: A Climate Change for Assessing Exclusionary Conduct under Article 102 TFEU, (2012) 4 J'nl of European Competition Law and Practice 32, J. Temple Lange and R O'Donoghue, 'Defining Legitimate Competition: How to Clarify Pricing Abuses under Article 102 EC' (2002) 26 Fordham International Law Journal 83, Nazzini, The Foundation of European Union Competition Law, the Objectives and Principles of Article 102 (Oxford University Press, 2011), 249 et seq. Geradin et al, EU Competition Law and Economics, 4.475-4.505. E Rousseva, Rethinking Exclusionary Abuses In Eu Competition Law (Hart Publishing, 2010), 215 et seq.
} 
Irish Sugar, that exclusionary price discrimination may be identified when a dominant firm employ a selective low pricing scheme (above cost) in an attempt to meet competition. ${ }^{40}$ The ECJ's clear statements in Post Danmark I saying that offering customers different prices cannot in itself be considered to be exclusionary conduct and that selective low pricing above ATC cannot have anti-competitive effect, sends a signal to narrow the ambit of Irish Sugar. Dominant firm can compete with the aim of not only meeting, but also beating, the competition. ${ }^{41}$ Stating this, I also hoped that Post Danmark $I$ would have restricted Article 102 (c) TFEU (secondary line discrimination), so that a dominant firm may selectively lower prices when it faces competition in a certain segment or in a certain geographic area. ${ }^{42}$ To be honest, in light of PD I, could Article 102 (c) TFEU be applicable when the court has stated that on the face of it, a discriminatory price has neither exclusionary, nor anticompetitive effects?

When reading Post Danmark II, I am not so certain anymore that PD I actually made an inroad to Article 102 (c) TFEU. Again, in PD II, it seems that rebate schemes must be available to all customers and that selective responses (even though not being loyalty inducing, nor creating prices below cost) to face off competition is seldom available for dominant firms. The case law under Article 102 (c) TFEU is also not 'crisp' enough in reference to "competitive disadvantage" that dominant firms can hope to escape the ambit of

\footnotetext{
${ }^{40}$ Irish Sugar [1997] (OJ L25/1). See also T-228/97, Irish Sugar, EU:T:1999:246. See also T-24/93 Compaignie Maritime Belge Transports SA v. Commission EU:T:1996:139. Where the use fo so-called 'fighting ship' strategy to target competitors where condemned under Article 102 TFEU on the basis that it was aimed to force a new entrant out of the market although the conduct neither violated teh AKZO test, nor fell within Article 102 (c) TFEU.

${ }^{41}$ See Commission decision in IV/31.900 - BPB Industries. See also Commission decision IV/35.471 - Digital Equipment Corp, where the Commission accepted undertakings to end proceedings under Article 102 TFEU that allowed non-standard price reductions were justified as proportionate respons to a competitor.

${ }^{42}$ In essence also restricting, Case C-395\&396/96P Compaignie Maritime Belge Transports SA v. Commission [2000] ECR I-1365. And the Advocate General's opinion, where the Advocate General Fennelly stated $\mathrm{n}$ para 132 "I would, on the other hand, accept that, normally, non-discriminatory price cuts by a dominant undertaking which do not entail below-cost sales should not be regarded as being anti-competitive. In the first place, even if they are only short lived, they benefit consumers and, secondly, if the dominant undertaking's competitors are equally or more efficient, they should be able to compete on the same terms. Community competition law should thus not offer less efficient undertakings a safe haven against vigorous competition even from dominant undertakings. Different considerations may, however, apply where an undertaking which enjoys a position of dominance approaching a monopoly, particularly on a market where price cuts can be implemented with relative autonomy from costs, implements a policy of selective price cutting with the demonstrable aim of eliminating all competition. In those circumstances, to accept that all selling above cost was automatically acceptable could enable the undertaking in question to eliminate all competition by pursuing a selective pricing policy which in the long run would permit it to increase prices and deter potential future entrants for $f$ ear of receiving the same targeted treatment." Even though the attempt and aim of Fennell is commendable, the situation above reflects competition and then anticompetitive conduct.
} 
Article 102 (c) TFEU when responding to a competitive threat. ${ }^{43}$ For example, in Irish Sugar there was no analysis whether the firms downstream that did not obtain the border rebate actually were in competition with those firms that did receive the rebate. Indeed, the General Court has stated that discriminatory prices tends to distort competition and there is no need to show actual competitive disadvantage in the case at hand. ${ }^{44}$ Moreover, if it is acceptable, according to PD I, to have selected rebate schemes vis-à-vis the contestable segment or costumers, that does not necessarily exclude a finding that those firm that do not obtain the rebate are in competitive disadvantage under the case law under Article 102 (c) TFEU. It would be unfortunate if selective responses that clear the hurdle of Post Danmark I would not be available for dominant firms, at least as objective justification under Article 102 (c) TFEU, i.e. under the meeting competition defence. Normal competitive behaviour for firms is to lower prices when they face competition, be it geographically, e.g. in reference to post services in the major cities, or in certain product segments, e.g. the low quality product segment that is heavily influenced by labour cost. ${ }^{45} \mathrm{~A}$ dominant firm will never face a new entrant that starts with entering every segment of the market. The new entrant will have an incentive to go for the high margin segments, and a dominant firm should be able to lower prices so to compete with the new entrant. This situation would lead to consumer welfare and lower prices. Indeed, if the dominant firm is forced to respond by lowering prices in all segments, prices are likely not going to be lowered in any segment.

\section{Conclusion}

For the supporters of an 'as-efficient'-competitor' test under Article 102 TFEU, PD II was a great disappointment. Given the fact that the Danish Court in its line of questions really had tried to pinpoint the Guidance paper, and explore whether the Guidance paper could be regarded as mirroring good law, the ECJ's judgement in PD II cast further doubt on the relevance and utility of the as-efficient-competitor test and thus, generally, the relevance and consistency of the European Commission's Article 102 Enforcement Priorities Guidance paper. Indeed, in paragraph 60 the CJEU goes as far as saying that in certain circumstances a

\footnotetext{
${ }^{43}$ Cf. T-228/97, Irish Sugar, EU:T:1999:246. See however Copmmission decision in IV/31.900 - BPB Industries.

${ }^{44}$ See Case C-95/04P British Airways [2007] ECR I-2331, para. 145.

${ }^{45}$ Moreover, there can be good economic arguments for price discrimination as a way to maximise economic efficieny. See Ramsey pricing in for example Bishop and Walker, The Economcis of EC Competition Law: Concepts, Application, and Measurement (3rd edn. 2010), paras. 6.34-6.36.
} 
less efficient competitor is preferable to no competition and requires the protection of Article 102.

The critique that was given vis-à-vis Intel may thus be recited again. James Venit, for example, stated that "(...) the problem with the Intel judgment is less its novelty than its failure to be novel in the spirit of Post Danmark I.. "46 There does not have to be any analysis of actual effects or consumer harm to determine the anticompetitive effects of discounts conditioned on exclusivity or quasi-exclusivity, even in an ex post case, and there is no de minimis threshold under Article 102. Also, there is no need to establish the existence of a causal link between the discount and the customer's purchasing decision. ${ }^{47}$

It is worth recalling that, according to rumours, PD II is the case in which the AdvocateGeneral prefaced her opinion by stating that "the Court should not allow itself to be influenced so much by current thinking ("Zeitgeist") or ephemeral trends". This ruling suggests the Court heeded her call and the judgment may yet prove controversial.

Leaving the general discussion behind, I have tried in this article to show that by upholding the case law doctrine for rebates while embracing an as-efficient-competitor test for price discrimination creates friction in the field of price discrimination where primary line discrimination and secondary line discrimination will be judged under very different tests. Moreover, there is a clear risk that competition will be restricted by the use of the old doctrine under Article 102 (c) TFEU, which Post Danmark II seems to suggest. Hopefully, the ECJ in the Intel appeal may give some guidance on how price discrimination should be judged and how Post Danmark I and II should be 'married'.

\footnotetext{
${ }^{46}$ James S. Venit, 'The EU General Court upholds the European Commission's Decision Regarding Exclusivity Rebates on the Microprocessor Market (Intel)', (June 2014) e-Competitions Bulletin, Art. N 67164 ${ }^{47}$ Ibid.
} 